\title{
ANTIOXIDANT EFFECTS ON VASCULAR ENDOTHELIAL CELLS INDUCED BY ACTIVE COMPONENTS OF PUNICA GRANATUM AND AMARANTHUS SP. EXTRACTS
}

\author{
CRISTINA DIȚESCU ${ }^{1}$, NARCISA BĂBEANU ${ }^{1}$, LAURA OLARIU ${ }^{2,3}$, BRÎNDUȘA DUMITRIU $^{2 *}$, \\ RALUCA PAPACOCEA ${ }^{4}$, OVIDIU POPA ${ }^{1}$, BRUNO ȘTEFAN VELESCU ${ }^{4}$ \\ ${ }^{I}$ University of Agronomical Sciences and Veterinary Medicine of Bucharest, 59 Mărăști Boulevard, 011464, Bucharest, \\ Romania \\ ${ }^{2}$ S.C. Biotehnos S.A., 3-5 Gorunului Street, 075100, Otopeni, Ilfov, Romania \\ ${ }^{3}$ Academy of Romanian Scientists, 54 Splaiul Independenței Street, 050094, Bucharest, Romania \\ 4 "Carol Davila" University of Medicine and Pharmacy, 37 Dionisie Lupu Street, 020021, Bucharest, Romania
}

*corresponding author: dbrandusa@biotehnos.com

Manuscript received: November 2018

\begin{abstract}
The intrinsic oxidative metabolism generates reactive oxygen species contributing to enzymatic modulation and signalling cascades. They interfere with pathological phenomena by the imbalance between endogenous antioxidant activity and extrinsic oxidative stress. Natural antioxidants are counteracting this imbalance, proving high value in preventive or complementary therapies of some serious diseases: atherosclerosis, diabetes, cancer, neurodegeneration. This study is focused on the evaluation at vascular endothelial cell (HUVEC) level of the intracellular glutathione as an activating factor of the intrinsic antioxidant system, as well as some reactive oxygen species (hydrogen peroxide and superoxide anion), oxidative stress generators. It has been investigated the cytotoxicity of pomegranate and amaranth extracts obtained through original biotechnology, as well as their ability to modulate these mechanisms. The results of applied flow cytometry techniques demonstrate the inhibition of reactive oxygen species by pomegranate atomized extract and the stimulation of intracellular glutathione by squalene from amaranth. As a consequence, it has been suggested the association of both extracts in order to achieve a two directions, concerted action in counteracting the cellular oxidative stress.
\end{abstract}

\section{Rezumat}

Metabolismul oxidativ intrinsec generează specii oxigen reactive care contribuie la modulări enzimatice și cascade de semnalizare, ce intervin în instalarea fenomenului patologic, prin dezechilibrul între activitatea antioxidantă endogenă și stresul oxidativ extrinsec. Antioxidanții naturali constituie o sursă de combatere a acestui dezechilibru, fiind pusă în valoare prin terapii de prevenție sau complementare a unor maladii grave: ateroscleroza, diabet, cancer, neurodegenerare. Lucrarea prezintă un studiu direcționat către evaluarea la nivel de celulă endotelială vasculară (HUVEC) a capacitații de producere intracelulară a glutationului, ca factor activator al sistemului antioxidant intrinsec, precum şi a unor specii oxigen reactive (peroxid de hidrogen și anion superoxid), generatoare de stres oxidativ celular. S-a investigat citocompatibilitatea extractelor de rodie și amarant obținute prin tehnologii originale și capacitatea acestora de a se implica în modularea acestor mecanisme. Utilizând tehnici de citometrie în flux, rezultatele au demonstrat inhibiția speciilor oxigen reactive de către extractul atomizat de rodie și stimularea glutationului intracelular de către squalenul din amarant. S-au evidențiat astfel, prin asocierea celor două componente vegetale, două direcții de acțiune centrate pe combaterea stresului oxidativ celular.

Keywords: antioxidant, pomegranate extracts, squalene, amaranth, HUVEC cells, intracellular glutathione, reactive oxygen species

\section{Introduction}

The intrinsic mitochondrial oxidative metabolism generates radical and non-radical reactive oxygen species (ROS), formed by the partial reduction of oxygen. ROS represent a cellular response to cytokines, xenobiotics, or bacterial invasion. The superoxide anion is produced via different metabolic pathways mediated by pathological and physiological stimuli. The superoxide anion is the precursor of hydrogen, peroxynitrite, and other species that modulates the enzymatic activity, the signal transduction cascades and the cellular oxidative stress [22]. The oxidative stress' induction is due to the increase of ROS or other oxidative species that reduce the cells capacity to grant an effective antioxidant response. As a consequence, there are generated critical signalling molecules involved in cell proliferation and survival, along with macromolecular damages responsible for various diseases: atherosclerosis, diabetes, cancer, neurodegeneration, and aging [24]. Cardiovascular disease, preceded by vascular endothelial dysfunction, is also coordinated by redox balance deregulations. Exogenous antioxidants are recommended as a therapeutic approach for preventing cells apoptosis 
and reducing risk factors like oxidized LDL, hyperglycaemia, or free fatty acids. Plants are considered to be effective antioxidant resources due to their content of compounds like flavones, polyphenols, vitamins, pigments, with antioxidant effects $[10,18$, 29]. For example, pomegranate, Punica granatum L. (Punicaceae), is a plant known for the phytoterapeutic properties (antioxidant, anti-inflammatory, nephroprotective, hepatoprotective, neuroprotective, anticancer, enhancing the immune system, enhancing carbohydrate metabolism and reducing insulin resistance) of the seed oil or fruit extracts $[1,6]$.

Punica granatum L. seed oil contains biological active compounds like punicic acid (PA), a conjugated isomer of $\alpha$-linolenic acid, sterols, fatty-acids [32] and the extracts of Punica granatum fruits are rich in antioxidant tannins and flavonoids $[17,28]$. Studies performed on the pomegranate fruit extracts demonstrated in vitro antioxidant properties [5], chemo preventive and/or anti-cancer effects in several animal models or standardised cells derived from human colon (HT29, HCT116), liver (HepG2, Huh7), breast (MCF-7, MDA-MB-231) and prostate (DU145) cancer lines $[5,7,17,28]$. Punica granatum extract inhibits the release of pro-inflammatory cytokines (TNF- $\alpha$ and IL-6) and anti-angiogenic factors (sFlt-1 and sEng) of endothelial cells HUVEC [1].

Amaranthus hypochondriacus L. and Amaranthus cruentus (Amaranthaceae) represent another resource of antioxidant compounds. The amaranth seeds oil's contains squalene a compound with antioxidant, and hepatotropic properties [2, 12, 18, 20].

The aim of the study was to evaluate the in vitro $[9,26]$ vasoprotective action of pomegranate and amaranth extracts, in respect with their cytotoxic profile and intrinsic/extrinsic antioxidant effects (intracellular glutathione, superoxide anion, hydrogen peroxide) on pro-inflammatory stimulated human umbilical vein endothelial cells (HUVEC).

\section{Materials and Methods}

\section{Reagents}

CellTiter $96^{\circledR}$ AQueous One Solution Cell Proliferation Assay (MTS), Promega G 3582; CytoTox $96^{\circledR}$ NonRadioactive Cytotoxicity Assay, Promega G 1780; 2',7'-Dichlorodihydrofluorescein diacetate (DCFHDA), Sigma D6883; Dihydroethidium (HE), Sigma D-7008; Fixation and permeabilization solution Cytofix/Cytoperm BD Bioscience, cat.no. 554722; anti-von Willebrand factor antibody (ABCAM, ab6994); goat anti-rabbit IgG H\&L (Alexa Fluor ${ }^{\mathbb{R}}$ 488) (ABCAM ab150077); rabbit IgG, polyclonal - Isotype Control (ChIP Grade) (ab171870); anti-glutathione antibody [D8] (ABCAM, ab19534); goat anti-mouse IgG H\&L (Alexa Fluor $^{\circledR}$ 488) (ABCAM, ab150113); mouse IgG2a, kappa monoclonal [MG2a-53] - isotype control (ABCAM, ab18415).

\section{Equipments}

Tristar LB941 plate reader, Berthold Technologies; Flow cytometer FACS CANTO II with DIVA 6.1 software.

Plant extracts

The pomegranate oil and atomized extract were obtained from pomegranates purchased from the Romanian market (imported from Turkey). The peels and seeds were manually separated. The pomegranate seeds were milled (Grindomix GM200 knife mill) and the oil was extracted with supercritical $\mathrm{CO}_{2}$ (SFC100-Thar). The oil contains 49\% punicic acid, and for the tests it was used a $20 \%$ stock fine dispersion in DMSO.

Pomegranate peels were dried to brittleness (vacuum oven $45^{\circ} \mathrm{C}, 40 \mathrm{~h}$ ) and milled to mesh no. 40 . The powder was extracted with $70 \%$ ethanol (15:1 solvent/ powder ratio, $\left.40^{\circ} \mathrm{C}, 6 \mathrm{~h}\right)$. After filtration $(0.45 \mu \mathrm{m})$ the extract was concentrated under vacuum $\left(40^{\circ} \mathrm{C}\right)$ and then sprays dried (Buchi B290). The atomized extract contains $38.7 \%$ punicalagin, and for the tests it was used as $14 \mathrm{mg} / \mathrm{mL}$ stock solution.

The amaranth seed oil was extracted with $\mathrm{SC}-\mathrm{CO}_{2}$ [4] and purified by short-path distillation (VKL-70-4 Short Path Distllation Unit, WTW). The oil contains $96.7 \%$ squalene and for the tests it was used a $20 \%$ stock solution in DMSO.

Cell cultures

HUVEC-C (ATCC ${ }^{\circledR}$ CRL1730 ${ }^{\text {TM }}$ ) cell line was used. The cultivation was performed at $37^{\circ} \mathrm{C}$, in $95 \%$ humidified air with $5 \% \mathrm{CO}_{2}$, using $\mathrm{F} 12 \mathrm{~K}$ Medium (ATCC 302004), supplemented with $0.1 \mathrm{mg} / \mathrm{mL}$ heparin (Sigma \#H3393) and endothelial cell growth supplement (ECGS; BD Biosciences \#354006). The human endothelial cells (passages 2 - 5) were cultivated in standard conditions previously described, with a $24 \mathrm{~h}$ adhesion time before the $48 \mathrm{~h}$ incubation with the active principles. The pro-inflammatory conditions were mimicked through two types of stimuli: TNF $\alpha$ and PMA (phorbol myristate acetate), relevant for the pro-oxidative status that accompanies the inflammation. The positive controls used were $\mathrm{N}$-acetyl-cysteine for the antioxidant effect and dexamethasone for the anti-inflammatory effect.

The cell line specificity was checked through antiVon Willebrand Factor staining of HUVEC cells. After the cellular permeabilization, the primary antibody $(1 \mu \mathrm{g} / \mathrm{mL})$ was incubated with the cells suspension for 30 minutes, on ice. Cells were washed and stained with the secondary antibody coupled with Alexa 488 with FITC emission, then analysed through flow cytometry, together with their isotype control [11]. The cell cytotoxicity was assessed through the evaluation of the metabolic activity of the cells (MTS test), correlated with the toxicological impact of the extracts expressed by the extracellular release of lactate dehydrogenase due to membrane leakage - (LDH assay) $[14,15,25]$. MTS is a tetrazolium salt reduced 
by $\mathrm{NAD}(\mathrm{P}) \mathrm{H}$-dependent dehydrogenase enzymes of viable cells to a coloured formazan dye soluble in cell culture media. The absorbance of the formazan dye is quantified at $490-500 \mathrm{~nm}$.

The intracellular glutathione content evaluation by flow cytometry was performed by labelling the cells with fluorescent antibodies: ABCAM anti-glutathione primary antibody and the secondary antibody - AlexaFluor 488 - FITC conjugated. The flow cytometry assay shows distinctive fluorescence function regarding the reduced intracellular glutathione content (GSH). Isotype controls were assessed as negative control and were designed to measure the level of nonspecific background signal. The protocol is similar with that used for anti-von Willebrand factor staining $[8,14]$. The results were expressed as mean fluorescence of the sample from which was subtracted the isotype control's mean fluorescence.

The intracellular oxygenated radicals simultaneous identification by flow cytometry (superoxide and hydrogen peroxide) was performed by staining the cells with dichloro-dihydro-fluorescein diacetate (DCFH-DA) and hydroethidine (HE) [3].

Statistical analysis

Data are expressed as mean \pm standard deviation (SD), averaged over at least three independent experiments for normally distributed data. We consider $* \mathrm{p}<0.05$, $* * \mathrm{p}<0.01, * * * \mathrm{p}<0.001, * * * * \mathrm{p}<0.0001$, using Repeated Measures ANOVA, Tukey Comparison Test (compare all pairs of data).

\section{Results and Discussion}

Cell line specificity

The cell line specificity was assessed by the staining of the von Willebrand factor that represents the main characteristic of endothelial primary cells [30]. The flow cytometry data showed a good preservation of the von Willebrand factor in the HUVEC cell line used for experiments (Figure 1).
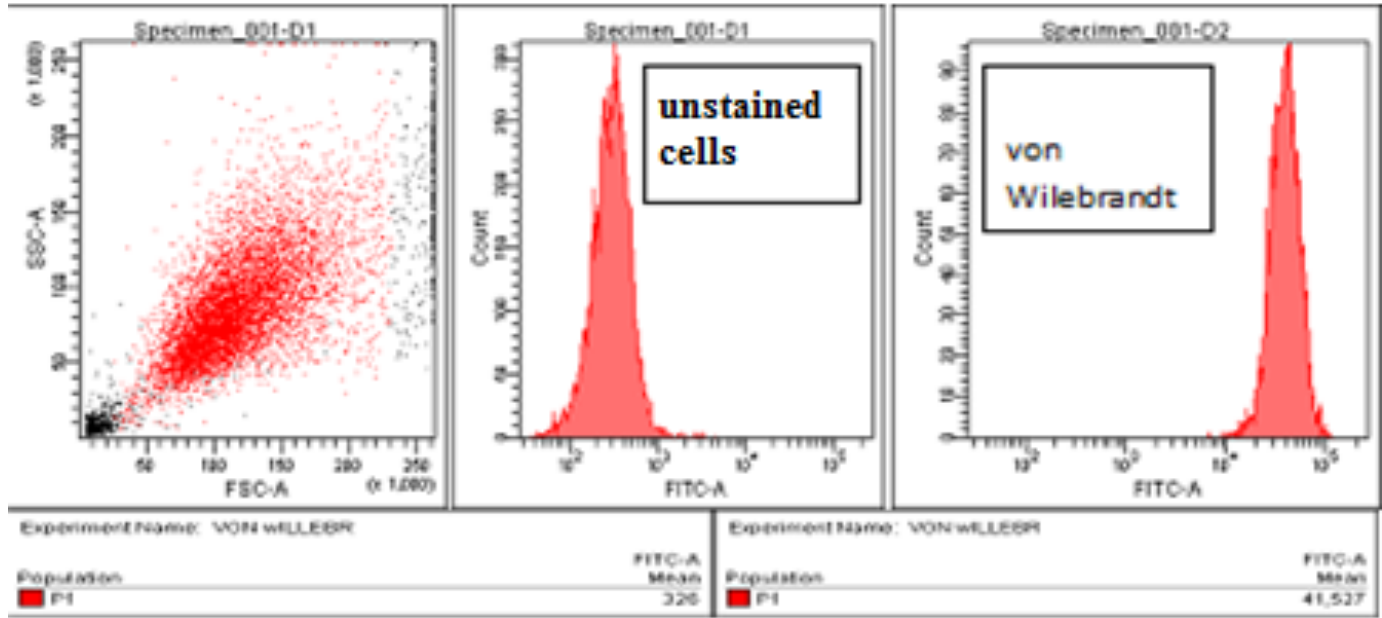

Figure 1.

HUVEC cell line that express Von Willebrand Factor (FITC-A fluorescent emission)

Cellular cytotoxicity

The cytotoxicity screening was performed in order to check the cyto-compatibility between the vegetal extracts and human vascular endothelial cells. After
$48 \mathrm{~h}$ of cell incubation with progressive concentrations of extracts, the metabolic activity (MTS) assay and the extracellular release of lactate dehydrogenase (LDH) test were assessed (Figure $2 \mathrm{a}, 2 \mathrm{~b}$ and $2 \mathrm{c}$ ).

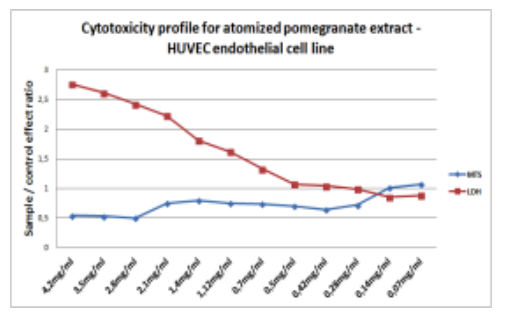

(a)

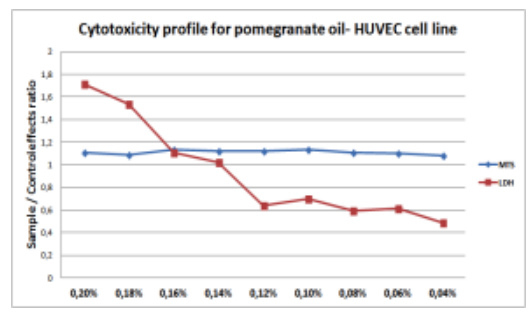

(b)

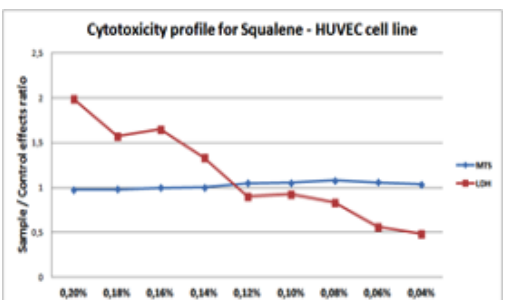

(c)

Figure 2.

Cytotoxicity curves express the metabolic activity (MTS) and the toxic impact (LDH) of the atomized pomegranate extract (a); pomegranate oil (b) and squalene (c) 
The inflexions points of MTS/LDH curves represent the limit concentrations of the tested compounds for cells survival at a normal metabolic activity. The results indicated the following maximum cytocompatibility doses of the tested compounds: $0.2 \mathrm{mg} / \mathrm{mL}$ pomegranate extract, $0.16 \%$ pomegranate oil, and $0.13 \%$ squalene from amaranth. The doses used for the evaluation of the extracts antioxidant effects were selected according to Figure 2 and were below the cytocompatibility threshold, respectively pomegranate atomized extract $0.14 \mathrm{mg} / \mathrm{mL}, 0.07 \mathrm{mg} / \mathrm{mL}$, pomegranate oil $0.04 \%$, squalene $0.04 \%, 0.02 \%$.

In order to investigate the antioxidant effects of the tested extracts, the pro-inflammatory and pro-oxidative status were assessed by cells stimulation with $10 \mu \mathrm{M}$ PMA, a protein-kinase $\mathrm{C}$ activator and oxidative burst trigger, and co-stimulation with $10 \mathrm{ng} / \mathrm{mL} \mathrm{TNF \alpha ,}$ one of the most active mediators of systemic inflammation [20].

Intracellular glutathione

The results of glutathione intracellular dynamics after pro-oxidative and pro-inflammatory stimulation, as well as the vegetal extracts' involvement in these mechanisms are presented in Table I.

Table I

Intracellular glutathione from human endothelial cells treated with bioactive pomegranate extracts (basal level/ pro-oxidative and pro-inflammatory stimulated)

\begin{tabular}{|c|c|c|}
\hline & \multicolumn{2}{|c|}{ pro-oxidative and pro-inflammatory stimule } \\
\hline & \multicolumn{2}{|c|}{ Intracellular glutathione (Fluorescence units on FITC-A) } \\
\hline & $\begin{array}{c}\text { Unstimulated cells } \\
\text { (mean of fluorescence units) }\end{array}$ & $\begin{array}{c}\text { Stimulated cells } \\
\text { (mean of fluorescence units) }\end{array}$ \\
\hline Cellular control & $2612 \pm 49$ & $1428 \pm 15$ \\
\hline Dexamethasone $200 \mathrm{ng} / \mathrm{mL}$ & $781 \pm 37 * * *$ & $897 \pm 45^{\mathrm{ns}}$ \\
\hline DMSO & $602 \pm 15$ & $890 \pm 16$ \\
\hline Pomegranate atomized extract $0.14 \mathrm{mg} / \mathrm{mL}$ & $830 \pm 22 * * *$ & $1370 \pm 33^{\text {ns }}$ \\
\hline Pomegranate atomized extract $0.07 \mathrm{mg} / \mathrm{mL}$ & $964 \pm 22 * * *$ & $942 \pm 20 * * *$ \\
\hline Pomegranate oil $0.04 \%$ & $836 \pm 10 * * *$ & $1092 \pm 88^{*}$ \\
\hline Squalene $0.04 \%$ & $1241 \pm 49 * * *$ & $1898 \pm 152 * * *$ \\
\hline Squalene $0.02 \%$ & $1307 \pm 13^{* * *}$ & $1672 \pm 31 * * *$ \\
\hline $\mathrm{N}$-acetyl-cysteine $0.5 \mathrm{mM}$ & $2978 \pm 72 * * *$ & $1887 \pm 82 * * *$ \\
\hline
\end{tabular}

The reduced intracellular glutathione decreased as a consequence of pro-oxidative and pro-inflammatory stimulation [16]. The hydrophilic complexes from pomegranate atomized extract accelerate the glutathione transformation, in both unstimulated and stimulated conditions, suggesting a negative impact on the antioxidant defence. The lipophilic compounds from pomegranate oil and amaranth raised the intracellular glutathione, as intrinsic protection against inflammatory disorders, similar with the positive control, N-acetylcysteine, known for its role in this mechanism. Dexamethasone, an anti-inflammatory agent does not interfere with glutathione's homeostasis when endothelial cells are stimulated by TNF $\alpha$ and PMA, and exerted antioxidant effect in basal condition, similar with data found in literature [23].

Oxidative stress biomarkers

The vegetal extracts' impact on cellular defence processes against the reactive oxygen species was evaluated through flow cytometry, as their ability to reduce the $\mathrm{H}_{2} \mathrm{O}_{2}$ and $\mathrm{O}_{2}{ }^{-}$intracellular level (Figure 3). The results and the statistical significance are presented in Table II.
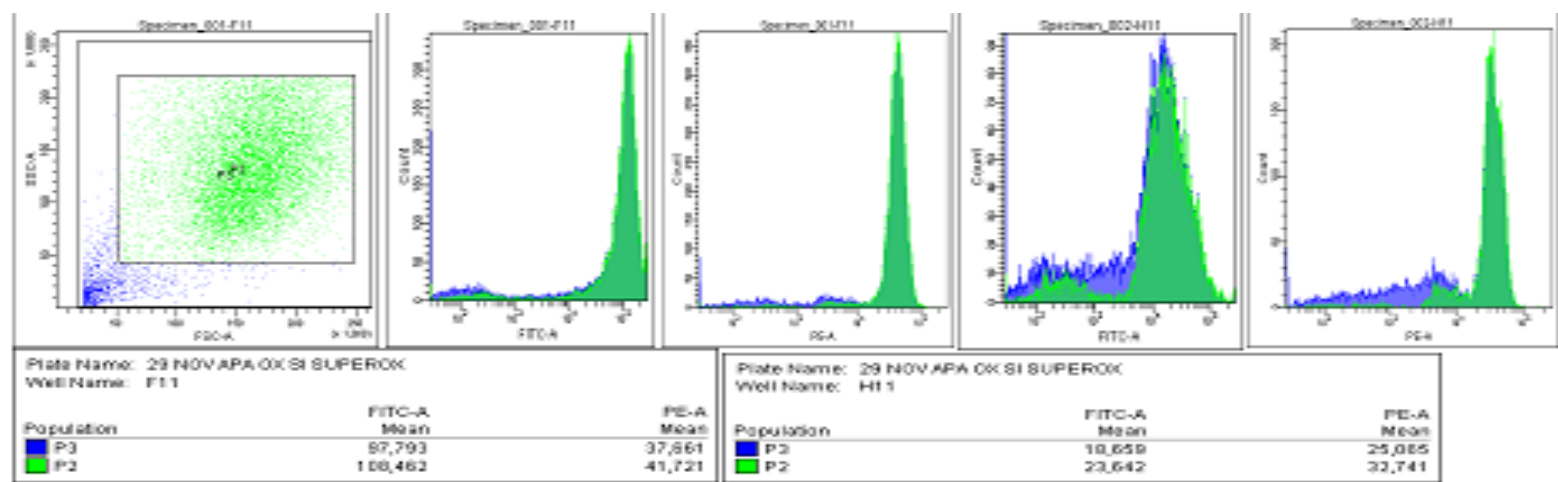

\section{Figure 3.}

The highlight of endothelial cells population (FSC /SSC coordinates) and fluorescence histograms corresponding to intracellular hydrogen peroxide (FITC $-\mathrm{A})$, and superoxide anion (PE-A) respectively 
Table II

Reactive oxygen species from human endothelial cells treated with the tested compound (basal level/prooxidative and pro-inflammatory stimulated)

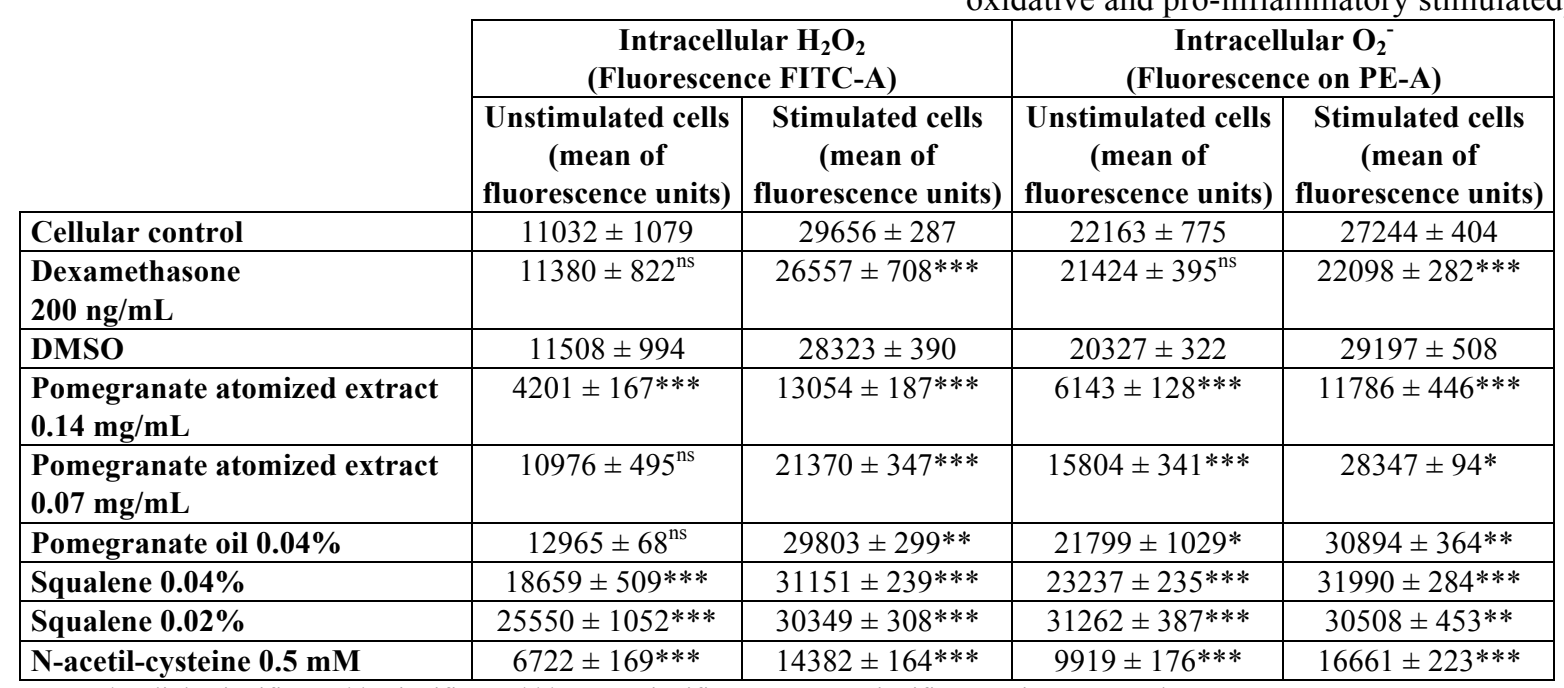

$\mathrm{p}<0.05, *$ - slight significant, **- significant, *** - very significant, ns - not significant, using Repeated Measures ANOVA

The atomized pomegranate extract significantly inhibits the superoxide anion and hydrogen peroxide release, in un-stimulated experimental series, as well as proinflammatory and pro-oxidative ones, proving the antioxidant effects at endothelial level. The liposoluble compounds, squalene and pomegranate oil do not interact with intracellular reactive oxygen species, neither in basal, nor pro-inflammatory conditions, squalene having a slight pro-oxidant effect that could be taken into account. The antioxidant positive control, $\mathrm{N}$-acetyl-cysteine inhibits both reactive oxygen species, in a significant manner. Dexamethasone reduces the intracellular influx of superoxide anion and hydrogen peroxide in pro-inflammatory stimulated vascular endothelial cells.

The key role of glutathione and reactive oxygen species in oxidative processes homeostasis is well defined in the scientific literature, but efficient and complete solutions to preserve the redox balance could still be found. Previous data indicates the stimulation of intracellular glutathione level by an aqueous extract of Teucrium polium as a component of its hepatoprotective action [27]. As well, Herba Cistanches enhance the gluthatione redox cycling of cardiomyocytes [31]. The phenolic compounds and flavonoids from Cornus officinalis inhibit xanthineoxidase activity and reactive oxygen species generation [13].

Our studies reveal an important and less explored potential of the pomegranate extracts and amaranth oil as antioxidant agents on endothelial cells, part of the huge resources offered by the vegetal bioactive compounds.

\section{Conclusions}

Pomegranate and amaranth extracts show an endothelial cell-compatible profile, preserving the metabolic activity up to $0.2 \mathrm{mg} / \mathrm{mL}$ for pomegranate atomized extract, $0.16 \%$ for pomegranate oil and $0.13 \%$ for squalene from amaranth. The atomized pomegranate extract appears to be the most active of the tested series, the complexity of its components generating marked antioxidant effect at the vascular endothelium level by inhibiting the reactive oxygen species $\left(\mathrm{H}_{2} \mathrm{O}_{2}\right.$, $\mathrm{O}_{2}{ }^{-}$) released in pro-inflammatory and pro-oxidative conditions. Squalene from amaranth has an intrinsic antioxidant action on the pathway of stimulating intracellular glutathione content. Further studies are needed to investigate the potential therapeutic role of the tested samples in cardiovascular disease.

\section{Acknowledgement}

This paper was financially supported by "Carol Davila" University of Medicine and Pharmacy through Contract no. CNFIS-FDI-2019-0534 (MEDEX-II) funded by the Ministry of National Education of Romania, from the Institutional Development Fund for Public Universities - FDI 2019.

\section{References}

1. Ambarwati D, Fatmawati F, Nooryanto M, Santoso S, Candra S, Baktiyani W, Nurdiana N, Punica granatum fruit extract inhibits the production of pro-inflammatory cytokines and angiogenic factors of HUVEC cells induced by plasma from patients with pre-eclampsia. Clin Nutr Exp., 2017; 15: 9-14.

2. Araceli López-Mejía O, López-Malo A, Palou E, Antioxidant capacity of extracts from amaranth (Amaranthus hypochondriacus L.) seeds or leaves. Ind Crops Products, 2014; 53: 55-59. 
FARMACIA, 2019, Vol. 67, 4

3. Aranda A, Sequedo L, Tolosa L, Quintas G, Burello E, Castell JV, Gombau L, Dichloro-dihydro-fluorescein diacetate (DCFH-DA) assay: a quantitative method for oxidative stress assessment of nanoparticle-treated cells. Toxicol In Vitro, 2013; 27(2): 954-963.

4. Babeanu NE, Nita S, Popa O, Marin DI, Batrinescu Gh, Optimisation of squalene recovery from amaranth oil by short path distillation. Rev Chim (Bucharest), 2018; 68(2): 291-296.

5. Baumgartner-Parzer SM, Waldenberger FR, Freudenthaler A, Ginouvès-Guerdoux A, McGahie D, Gatto $\mathrm{H}$, The natural antioxidants, pomegranate extract and soy isoflavones, favourably modulate canine endothelial cell function. ISRN Veterinary Science, 2012; 2012: $1-12$.

6. Boroushaki MT, Mollazadeh H, Afshari AR, Pomegranate seed oil: a comprehensive review on its therapeutic effects. Int J Pharm Sci Res., 2016; 7(2): 1000-1013.

7. Costantini S, Rusolo F, De Vito V, Moccia S, Picariello G, Capone F, Guerriero E, Castello G, Volpe MG, Potential anti-inflammatory effects of the hydrophilic fraction of pomegranate (Punica granatum L.) seed oil on breast cancer cell lines. Molecules, 2014; 19: 8644-8660.

8. Dikalova AE, Itani HA, Nazarewicz RR, McMaster WG, Flynn CR, Uzhachenko R, Fessel JP, Gamboa JL, Harrison DG, Dikalov SI, Sirt3 impairment and SOD2 hyperacetylation in vascular oxidative stress and hypertension. Circ Res., 2017; 121: 564-574.

9. Dumitriu B, Olariu L, Nita R, Zglimbea L, Rosoiu $\mathrm{N}$, Vascular anti-inflammatory effects of natural compounds from Aesculus hippocastanum and Hedera helix. Rom Biotechnol Lett., 2013; 18(1): 7963-7974.

10. Fierascu I, Ungureanu C, Avramescu SM, Cimpeanu C, Georgescu MI, Fierascu RC, Ortan A, Sutan AN, Anuta V, Zanfirescu A, Dinu-Pirvu CE, Velescu BS, Genoprotective, antioxidant, antifungal and antiinflammatory evaluation of hydroalcoholic extract of wild-growing Juniperus communis L. (Cupressaceae) native to Romanian southern sub-Carpathian hills. BMC Complement Altern Med., 2018;18(1): 1-14.

11. Fotakis G, Timbrell JA, In vitro cytotoxicity assays: comparison of LDH, neutral red, MTT and protein assay in hepatoma cell lines following exposure to cadmium chloride. Toxicol Lett., 2006; 160(10): 171177.

12. He HP, Corke H, Oil and squalene in amaranthus grain and leaf. J Agric Food Chem., 2003; 51(27): 7913-7920.

13. Hwang KA, Hwang YJ, Song J, Antioxidant activities and oxidative stress inhibitory effects of ethanol extracts from Cornus officinalis on raw 264.7 cells. BMC Complement Altern Med., 2016; 16: 1-9.

14. Lindahl TL, Fagerberg IH, Larsson A, A new flow cytometric method for measurement of von Willebrand factor activity. Scand J Clin Lab Invest., 2003; 63(3): 217-223.

15. Malich G, Markovic B, Winder C, The sensitivity and specificity of the MTS tetrazolium assay for detecting the in vitro cytotoxicity of 20 chemicals using human cell lines. Toxicology, 1997; 24(3): 179-192.

16. Masella R, Di Benedetto R, Vari R, Filesi C, Giovannini $\mathrm{C}$, Novel mechanisms of natural antioxidant compounds in biological systems: involvement of glutathione and glutathione-related enzymes. $J$ Nutr Biochem., 2006; 16: 577-586.

17. Mertens-Talcott SU, Jilma-Stohlawetz P, Rios J, Hingorani L, Derendorf H, Absorption, metabolism, and antioxidant effects of pomegranate (Punica granatum L.) polyphenols after ingestion of a standardized extract in healthy human volunteers. $J$ Agric Food Chem., 2006; 54(23): 8956-8961.

18. Neagu AF, Costea T, Nencu I, Duţu LE, Popescu ML, Olaru OT, Gîrd CE, Obtaining and characterization of a selective Pelargonium graveolens l'hér. dry extract with potential therapeutic activity in metabolic diseases. Farmacia, 2018; 66(4): 592-596.

19. Nikolaevsky VA, Martirosyan DM, Muzalevskaya EN, Miroshnichenko LA, Zoloedov VI, Hepatotropic, antioxidant and antitoxic action of amaranth oil. Funct Foods Health Disease, 2014; 4(5): 159-171.

20. Olariu L, Dumitriu B, Craciun L, Buse E, Rosoiu N, Bojinca $\mathrm{M}$, Papacocea $\mathrm{T}$, The in vitro influence of a pharmaceutically active small sea fish extract on apoptosis and proliferation mechanisms amplified by inflammatory conditions. Farmacia, 2018; 66(3): 524-529.

21. Paśko P, Bartoń H, Fołta M, Gwizdz J., Evaluation of antioxidant activity of amaranth (Amaranthus cruentus) grain and by-products (flour, popping, cereal). Rocz Panstw Zakl Hig., 2007; 58(1): 35-40.

22. Quijano C, Castro L, Pellufo G, Valez V, Radi R, Enhanced mitochondrial superoxide in hyperglycemic endothelial cells: direct measurements and formation of hydrogen peroxide and peroxynitrite. Am J Physiol Heart Circ Physiol., 2007; 293(6): 3404-3414

23. Raffaele N, Marchese A, Ghigo D, Compared antioxidant activity among corticosteroids on cultured retinal pigment epithelial cells. Graefes Arch Clin Exp Ophthalmol., 2016; 254(12): 2411-2416.

24. Ray PD, Huang BW, Tsuji Y, Reactive oxygen species (ROS) homeostasis and redox regulation in cellular signaling. Cell Signal., 2012; 24(5): 981-990.

25. Riss TL, Moravec RA, Improved non-radioactive assay to measure cellular proliferation or toxicity: the CellTiter $96^{\circledR}$ AQueous One Solution cell proliferation assay. Promega Notes, 1996; 59: 19-23.

26. Safaeian L, Javanmard SH, Mollanoori Y, Dana N, Cytoprotective and antioxidant effects of human lactoferrin against $\mathrm{H}_{2} \mathrm{O}_{2}$-induced oxidative stress in human umbilical vein endothelial cells. Adv Biomed Res., 2015; 2015; 4: 188.

27. Shtukmaster S, Ljubuncic P, Bomzon A, The effect of an aqueous extract of Teucrium polium on glutathione homeostasis in vitro: A possible mechanism of its hepatoprotectant action. Adv Pharm Sci., 2010; 2010: 1-7.

28. Syed DN, Chamcheu JC, Adhami VM, Mukhtar H, Pomegranate extracts and cancer prevention: molecular and cellular activities. Anticancer Agents Med Chem., 2013; 13(8): 1149-1161.

29. Velescu BS, Anuta V, Nitulescu GM, Olaru OT, Ortan A, Ionescu D, Ghica MV, Dragoi CM, Dinu Pirvu CE, Pharmaceutical assessment of Romanian crops of Anthriscus sylvestris (Apiaceae). Farmacia, 2017; 65(6): 824-831. 
30. Wissink MJB, Beernink R, Poot AA, Engbers GHM, Beugeling $\mathrm{T}$, van Aken WG, Feijen J, Relation between cell density and the secretion of von Willebrand factor and prostacyclin by human umbilical vein endothelial cells. Biomaterials, 2001; 22(16): 2283-2290.

31. Wong HS, Ko KM, Herba cistanches stimulates cellular glutathione redox cycling by reactive oxygen species generated from mitochondrial respiration in H9c2 cardiomyocytes. Pharm Biol., 2013; 51(1): 64-73.

32. Zahra A, Lazreg-Aref H, Mekni M, El-Gharbi S, Dabbaghi O, Mechri B, Oil characterization and lipids class composition of pomegranate seeds. Biomed Res Int., 2017; 2017: 1-9. 